\title{
Ion Transport
}

Edited by

\section{DAVID KEELING}

Smith Kline \& French Research Limited Welwyn, Hertfordshire, UK

\section{CHRIS BENHAM}

Smith Kline \& French Research Limited Welwyn, Hertfordshire, UK

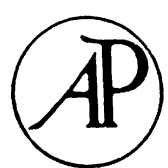

\section{ACADEMIC PRESS}

Harcourt Brace Jovanovich Publishers

London San Diego New York Berkeley

Boston Sydney Tokyo Toronto 


\section{ACADEMIC PRESS LIMITED \\ 24/28 Oval Road \\ London NW1 71)X}

\section{Uniled States Edition published by ACADE.MIC PRESS INC: \\ San Dicgo, CA 92101}

Copyright (C) 1989 by ACADEMIC: PRESS LIMIITED

\section{Except Chapter 12 (C) US Government}

This book is printed on acid-frec paper $\otimes$

All Rights Reserved

No part of this book may be reproduced in any form, photostat, microfilm, or by any other means. without written permission from the publishers

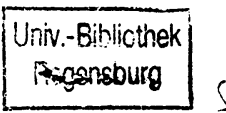

British Library Cataloguing in Publication Data is available

ISBN $(0-12-403985-5$

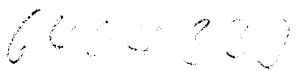

Typeset by Photographics, Honiton, Deron Printed in Great Britain by St Edmundsbury Press I.td. Bury St Edmunds, Suffolk 


\section{Contributors}

P.I. Aaronson Department of Pharmacology, St George's Hospital Medical School, Cranmer Terrace, Tooting, London SW17 ORE, UK

M.H. Akabas Departments of Medicine and Physiology, Columbia University, College of Physicians and Surgcons, $630 \mathrm{~W}$ 168th Strect, New York, N.Y., USA

Q. Al-Awqati Departments of Medicine and Physiology, Columbia University, College of Physicians and Surgcons, $630 \mathrm{~W}$ 168th Strect, Ncw York, N.Y., USA

R.W. Aldrich Department of Ncurobiology, Stanford University School of Mcdicine, Stanford, Calif. 94305-5401, USA

D. Anderson CURE, Wadsworth VA and UCLA, Los Angeles, Calif., USA

D. Aures-Fischer CURE, Wadsworth VA and UCLA, Los Angeles, Calif., USA

E.A. Barnard MRC Molecular Ncurobiology Unit, MRC Centre, Hills Road, Cambridgc CB2 2QH, UK

L. Bianchini University Laboratory of Physiology, Parks Road, Oxford OXI 3PT, UK

G. Belagi Allcrgan, Irvinc, Calif., USA

C.D. Benham Smith Kline \& French Rescarch Limited, The Frythe, Welwyn, Herts AL5 9AR, UK

M. Biel Institut für Physiologische Chemic, Medizinische Fakultät, Universität des Saarlandes, D-6650 Homburg/Saar, West Germany

T.B. Bolton Department of Pharmarology, St Gcorge's Hospital Medical School, Cranmer Terrace, Tooting, London SW17 ORE, UK 
M.S. Brainard Department of Neurobiology, Stanford University School of Medicine, Stanford, Calif. 94305-j401, USA

M.G. Darlison MRC Molecular Neurobiology Unit, MRC Cientre, Hills Road, Cambridge CB2 2QH, UK

A.C. Dolphin Department of Pharmacology, St George's Hospital Medical School, Cranmer Terrace, Tooting, London SWl7 ORE, UK

A. Edelman Departments of Medicine and Physiology, Columbia University, College of Physicians and Surgeons, 630 W 168th Strect, New York, N.Y., USA

D.T. Edmonds The Clarendon Laboratory, Parks Road, Oxford OXI 3PU, UK

J.C. Ellory University Laboratory of Physiology, Parks Road, Oxford OXl 3P'T, UK

V. Flockerzi Institut für Physiologische Chemic, Medizinische Fakultät, Universität des Haarlandes, D-6650 Homburg/Saar, West Germany

L. Gerlach Physiologisches Institut, Albert Ludwigs Universität Freiburg, Hermann Herder Strasse 3, D-7800 Freiburg, West Germany

R. Greger Physiologische Institut, Albert Ludwigs Universität Freiburg, Hermann Herder Strasse 3, D-7800 Freiburg, West Germany

A.C. Hall University Laboratory of Physiology, Parks Road, Oxford OXl 3PT, UK

K. Hall CURE, Wadsworth VA and UCIA, Los Angeles, Calif., LSA

S. Hering Department of Pharmacology, St Gcorge's Hospital Medical School, Cranmer Terrace, Tooting, I,ondon SW'17 ORE, UK

S.J. Hersey Emory University, Atlanta, Georgia, USA

P. Hess Department of Cellular and Molecular Physiology, Harvard Medical School, 25 Shattuck Strect, Boston, Mass. 02115. US.

B. Hille Department of Physiology and Biophysics, SJ-40, Washington University, Scattle, Wash. 98195, USA

S.B. Hladky Department of Pharmacology, University of Cambridge, Cambridge CB2 2QD, UK

F. Hoffman Institut für Physiologische Chemic, Medizinische Fakultät, Universität des Saarlandes, D-6650 Homburg/Saar, West Germany 
S.J.D. Karlish Department of Biochemistry, Weizmann Institute of Science, Rehovoth, Isracl

K. Kunzelmann Physiologisches Institut, Albert Ludwigs Universität Freiburg, Hermann Herder Strasse 3, D-7800 Freiburg, West Germany

D.W. Landry Departments of Medicine and Physiology, Columbia University, College of Physicians and Surgeons, $630 \mathrm{~W} 168 \mathrm{th}$ Strect, New York. I.Y.. USA

D.E. Logothetis Department of Cardiology at Children's Hospital, Harvard Medical School, Boston, Mass. 0211j, USA

M.L. Mayer Unit of Neurophysiology and Biophysics, Building 36, Room 2A21, I.DN, NICHD, NIH, Bethesda, Md. 20892, USA

J. Marshall MRC Molecular Neurobiology Unit, MRC: Cicntre, Hills Road, Cambridge CB2 2QH, UK

J.E. Merritt Smith Kline \& French Research Limited, The Frythe, Welwyn. Herts ALj 9AR, UK

K. Munson CURE, Wadsworth VA and UCLA, Los Angeles, Calif., USA

R.K. Nakamoto Department of Human Genetics \& Cellular and Molecular Physiology, Yale University School of Medicine, New Haven, Conn. 06510, USA

M.R. Plummer Department of Cellular and Molecular Physiology, Harvard Medical School, 25 Shattuck Strect, Boston, Mass. 02115, USA

H. Porzig Department of Pharmacology, University of Berne, $\mathrm{CH}-3010$, Berne, Switzerland

R. Rao Department of Human Genctics \& Cellular and Molecular Physiology, Yale University School of Medicine, New Haven, Comn. 06510, USA

C. Redhead Departments of Medicine and Physiology, Columbia University, College of Physicians and Surgeons, $630 \mathrm{~W}$ 168th Strect, New York, N.Y., USA

H. Reuter Department of Pharmacology, University of Berne, C.H-3010 Berne, Switzerland

T.J. Rink Smith Kline \& French Research Limited, The Frythe, Welwyn, Herts AL.5 9AR, UK 
P. Ruth Institut für Physiologisches Chemic, Medizinische Fakultät, Universität des Saarlandes, D-6650 Homburg/Saar, West Germany

G. Sachs CURE, Wadsworth VA and UCLA, Los Angeles, Calif., USA D.B. Sattelle AFRC Unit of Insect Neurophysiology and Pharmacology, Department of Zoology, University of Cambridge, Cambridge CB2 3BJ, UK

R.H. Scott Department of Pharmacology, St George's Hospital Medical School, Cranmer Terrace, Tooting, London SW17 ORE, UK

C.W. Slayman Department of Human Genetics \& Cellular and Molecular Physiology, Yalc University School of Medicine, New Haven, Conn. 06510, USA

C.K. Solc Department of Ncurobiology, Stanford University School of Medicine, Stanford, Calif. 94305-5401, USA

W.N. Zagotta Department of Ncurobiology, Stanford University School of Medicinc, Stanford, Calif. 94305-5401, USA 


\section{Contents}

Contributors. . . . . . . . . . . . . . . . . . . . . . v v Forrword . . . . . . . . . . . . . . . . . in

Introduction . . . . . . . . . . . . . . . . . . . xili

\section{PART 1: P-type Cation Pumps}

\section{Extracytosolic Functional Domains of the $\mathbf{H}^{+}, \mathrm{K}^{+}$-ATPase}

\section{Complex}

G. Sachs, K. Munson, K. Hall, D. Aures-Fischer, D). Anderson. I: Belagi and S.J. Hersey

l Introduction. . . . . . . . . . . . . . . . . . . . . . . 3

2 Results. . . . . . . . . . . . . . . . . 6

3 Discussion ....................... 13

Acknowledgements. . . . . . . . . . . . . . . 16

Reforences ................... . . . 17

2 The Mechanism of Cation Transport by the $\mathrm{Na}^{\prime}, \mathrm{K}^{+}$-ATPase 19 S.J.l. Karlish

1 Introduction. . . . . . . . . . . . . . . . . . . . . . . . . . 19

2 The transport mechanism . . . . . . . . . . . . . . . . . 19

3 Cation occlusion. . . . . . . . . . . . . . . . . 21

+ Cation selectivity . . . . . . . . . . . . . . . . . 22)

5 Trans effects of $\mathrm{Na}^{+} \ldots \ldots . \ldots . \ldots . \ldots 23$

6) Cation slippaye fluxes . . . . . . . . . . . . . . 24

i Electrogenic potentials. . . . . . . . . . . . . . . 25

8 Effects of voltage on the pump . . . . . . . . . . . . 26

9 The structure of the cation-binding sites. . . . . . . . . . . . 29

10 Future directions . . . . . . . . . . . . . . . 30

Acknowledgements. . . . . . . . . . . . . . 31

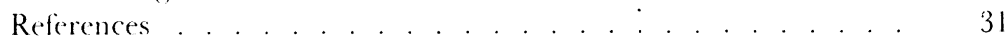


3 The Nucleotide-binding Site of the Plasma-membrane $\mathrm{H}^{+}$- ATPase of Neurospora crassa: A Comparison with other P-type ATPases

Rajini Rao, Roberl K. Nakamolo and Carolyn W. Slayman

1 Introduction. . . . . . . . . . . . . . . . . . . . 35

2 Nucleotide binding. . . . . . . . . . . . . . . . . . . . 37

3 Sequence comparisons . . . . . . . . . . . . . . . . . . . . . 39

4 Structure of the nucleotide-binding site . . . . . . . . . . . . . 47

Acknowledgements. . . . . . . . . . . . . . 50

References . . . . . . . . . . . . . . . 50

\section{PART 2: Ion Channels and their Modulation}

4 Voltage-gated Sodium Channels since 1952

Beril Hille

l Introduction. . . . . . . . . . . . . . . . . . . . . 57

2 Distribution. . . . . . . . . . . . . . . . . . 57

3 Molecular Structure. . . . . . . . . . . . . . . . . . . . 59

4 Gating . . . . . . . . . . . . . . . . . . . 60

5 Selectivity filter and pore. . . . . . . . . . . . . 63

6 Modulated receptors. . . . . . . . . . . . . . . . . . 64

7 Conclusion . . . . . . . . . . . . . . . . 68

Acknowledgements. . . . . . . . . . . . . . . . . . . 69

References . . . . . . . . . . . . . . . 69

5 Single Potassium Channels in Drosophila Nerve and Muscle

Richard W. Aldrich, Charles K. Solc, William N. Zagolla and

Michael S. Brainard

l Introduction. . . . . . . . . . . . . . . . . . . . 73

2 Advantages of Drosophila as a system for the study of ion channels 73

3 Tissue culture systems . . . . . . . . . . . . . . . . 75

$4 \Lambda_{1}$ channels. . . . . . . . . . . . . . . . . . 77

$5 \Lambda_{2}$ channels. . . . . . . . . . . . . . . . . . . . 78

$6 \mathrm{~K}_{1}$ ) channels . . . . . . . . . . . . . . . . . . . . . . 79

$7 \mathrm{~K}_{1}$ channels. . . . . . . . . . . . . . . . . . . 80

$8 \mathrm{~K}_{\mathrm{O}}$ channels .................. . . . . 81

$9 \mathrm{~K}_{\mathrm{ST}}$ channel ....................... . . . . 81

10 Shaker differential splicing does not explain the diversity of

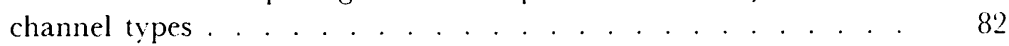

Acknowledgement . . . . . . . . . . . . . . 83

References ................. . . 84 
6 Calcium Channels: Properties and Modulation $\quad 87$

H. Reuter and H. Porzig

1 Introduction. . . . . . . . . . . . . . . . . . 87

$2 \mathrm{Ca}^{2+}$ channel selectivity . . . . . . . . . . . . . . . . 88

$3 \mathrm{Ca}^{2+}$ channel gating. . . . . . . . . . . . . . . . . . 88

$4 \mathrm{Ca}^{2+}$ channel modulation . . . . . . . . . . . . . 90

Acknowledgements. . . . . . . . . . . . . . . . . . . . . . 94

References . . . . . . . . . . . . . . . . . . . . . . 94

7 Calcium Channels in Mammalian Sympathetic Neurons and PC12 Cells

Mark R. Plummer, Peler Hess and Diomedes E. Logothetis

I Introduction. . . . . . . . . . . . . . . . . . . . 97

2 2

Acknowledgements. . . . . . . . . . . . . . . . 113

References ...................... 114

8 Voltage-dependent Calcium Channels of Smooth Muscle Cells

T.B. Bollon, S. Hering and P.I. Aaronson

1 Introduction. . . . . . . . . . . . . . . . . 117

2 Inward current . . . . . . . . . . . . . . . 118

3 Conclusions . . . . . . . . . . . . . . . . . . . 123

Acknowledgements. . . . . . . . . . . . . . . . . . . . 124

References . . . . . . . . . . . . . . . . 124

9 Modulation of Calcium and other Channels by G Proteins: Implications for the Control of Synaptic Transmission

Annelle C. Dolphin and Roderick H. Scoll

l Introduction. . . . . . . . . . . . . . . . . 127

2 Modulation of $\mathrm{Ca}^{2+}$ channels by $\mathrm{G}$ protein activation . . . . . 128

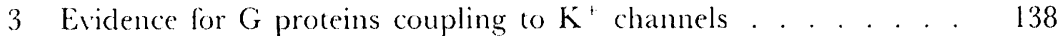

+ Role of $\mathrm{G}$ protein-coupled ion channels in the modulation of synaptic transmission . . . . . . . . . . . . . 140

5 Conclusion . . . . . . . . . . . . . . . . 141

References ..................... . . 142

10 The Structure of the Skeletal Muscle Calcium Channel 147

Peler Rulh, Veil Flockerzi, Marlin Biel and Franz Hoffman

1 Introduction. . . . . . . . . . . . . . . . 147

2 Structural composition of the purified skeletal muscle $\mathrm{Ca}^{2+}$ channel. 
3 Phosphorylation of the purified CaC.B-receptor. . . . . . . . . . $1+8$

4 Structure of the $\alpha_{1}$ - and $\beta$-subunits of the skeletal muscle $\mathrm{Ca}^{2+}$ channel. . . . . . . . . . . . . . . . . 150

5 Identification of L-type $\mathrm{Ca}^{2+}$ channel proteins in other tissues . . 152

6 Reconstitution of an L-type $\mathrm{Ca}^{2+}$ channel from the skeletal muscle CaCB-receptor . . . . . . . . . . . . . . . . . . 153

7 Conclusions. . . . . . . . . . . . . . . . . . . . . . . . . . 154

Acknowledgements. . . . . . . . . . . . . . . . . 154

References . . . . . . . . . . . . . . 155

11 Structural Characteristics of Cation and Anion Channels Directly Operated by Agonists

E.A. Barnard, M.G. Darlison, J. Marshall and D.B. Sallelle

l Classes of receptor-operated channels . . . . . . . . . . . . . . 159

2 Ligand-operated ion channels. . . . . . . . . . . . . . . 161

3 Vertebrate nicotinic acetylcholine receptors . . . . . . . . . . 162

4 Homo-oligomeric forms of nicotinic receptors in insects. . . . . . 166

j G.\B $\Lambda_{1}$ and glycine receptors . . . . . . . . . . . . . 171

6 The ion channel in the structure . . . . . . . . . . . . . 17t

7 Conclusions. . . . . . . . . . . . . . . . . . 175

References . . . . . . . . . . . . 176

12 Activation and Desensitization of Glutamate Receptors in Mammalian CNS

Mark L. Mayer

1 Introduction. . . . . . . . . . . . . . . . . . . . . . . . 183

2 Techniques used for rapid perfusion to limit descnsitization. . . 185

3 Responses to last applications of excitatory amino acids . . . . . 186

4 Glycine modulates desensitization at N.MDA receptors . . . . . . 188

5 Dosc-response analysis for activation of. $\mathrm{XID} 1$ and quisqualate receptors . . . . . . . . . . . . . . 189

6 Implications for synaptic transmission. . . . . . . . . . . . 191

Acknowledgements. . . . . . . . . . . . . . . . . 194

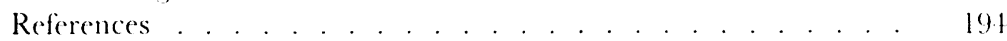

13 Receptor-mediated Calcium Entry 197

C.D. Benham, J.E. Merrill and T.J. Rink

l Introduction. . . . . . . . . . . . . . . . . . . . . . . . . . . 197

2 Electrophysiological approaches. . . . . . . . . . . . . . 199

3 Studies with fluorescent indicators of $\left[\mathrm{Ca}^{2+}\right]_{;} \ldots \ldots 203$

4 Conclusion . . . . . . . . . . . . . . . . . . . 210

Acknowledgements. . . . . . . . . . . . . . . . . . 211

References .................. 211 


\section{PART 3: Ions and Fluid Transport}

14 Pathways for Cell Volume Regulation via Potassium and Chloride Loss

A.C. Hall, L. Bianchini and J.C. Ellory

I Introduction: transport processes inwolved in RVD. . . . . . . . 217

2 Coupled KC:I co-transport in hepatocytes . . . . . . . . . . . 222

3 Anion dependence and kinetic properties of $\mathrm{KCl}$ co-transport in red cells........................ 224

+ Specific inhibitors of $\mathrm{KCl}$ co-transport . . . . . . . . . . . 226

5 Loss of $\mathrm{KC}$ (1 co-transport on "Young" red cell maturation. . . . . 228

(f) Discussion . . . . . . . . . . . . . . . . . . . . . . 229

Acknowledgements. . . . . . . . . . . . . 231

References .................. 231

15 Epithelial Chloride Channels: Properties and Regulation

R. Greger, L. Gerlach and K. Kunzelmann

l Introduction. . . . . . . . . . . . . . . . . . . . . . . 237

2 Properties of epithelial $\mathrm{Cl}^{-}$channels . . . . . . . . . . . . . 238

3 Regulation of epithelial $\mathrm{Cl}^{-}$channels . . . . . . . . . . . . 2 $2+1$

t Conclusion . . . . . . . . . . . . . . . . . . . . $24 t$

Acknowledgements. . . . . . . . . . . . . . 245

References . . . . . . . . . . . . . . . . . 245

16 Purification and Reconstitution of the Epithelial Chloride Channel

Donald I1. Landry, Myles H. Akabas, Chrislopher Redllead.

Aleksander Edelman and Qais Al-Awqali

1 Introduction. . . . . . . . . . . . . . . . . . . . . . . . . . 249

2 Solubilization and affinity chromatography . . . . . . . . . 250

3 Reconstitution. . . . . . . . . . . . . . . . . . . . 253

1 Discussion . . . . . . . . . . . . . . . . 20257

Acknowledgements. . . . . . . . . . . . . . . . 258

References . . . . . . . . . . . . . . 258

\section{PART 4: Models of Ion Permeation across Membranes}

17 Models of Ion Permeation through Membranes 263 S.B. Hladky

1 Introduction. . . . . . . . . . . . . . . . . . . . 263

2 Molecular and Brownian dynamics . . . . . . . . . . . . 264 
3 Interpretation of experimental data . . . . . . . . . 265

References . . . . . . . . . . . . . . . . 275

18 Topics Relating to the Modelling of Ion Channel Function 279 D.T. Edmonds

1 A threshold model of $\mathrm{Na}^{+}$channel kinetics . . . . . . . . . . . 279

2 A kinetic role for ionizable residues in channel proteins . . . . . 286

References . . . . . . . . . . . . . . . . 291

Appendix: Abstracts of Posters _. . . . . . . . . . . 293

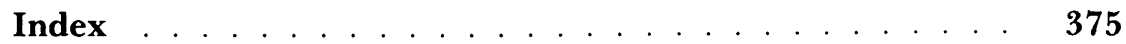

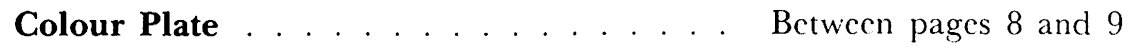




\title{
The Structure of the Skeletal Muscle Calcium Channel
}

\author{
PETER RUTH, VEIT FLOCKERZI, MARTIN BIEL and \\ FRANZ HOFFMAN
}

Institut für Physiologische Chemie, Medizinische Fakultät, Universität des Saarlandes, Homburg/Saar, West Germany

\section{Introduction}

Voltagc-activated $\mathrm{Ca}^{2+}$ channels are classificd into threc types (T, N and $\mathrm{L}$ ), which differ in their pharmacological behaviour and functional significance (Nowycky et al., 1985). L-type channels are sensitive to organic drugs the $\mathrm{Ca}^{2+}$ channel blockers $(\mathrm{CaCB})$ which include the dihydropyridines (1,4-DHPs), the phenylalkylamines (PAAs) and the benzothiazepines (BTZs) (Hofmann et al., ro 7 ). In cardiac muscle, $\beta$-adrenoceptor agonists increase the open state probability of this channel type either by phosphorylation of the channel or a channel associated protein via the catalytic subunit of cAMP-dependent protein kinase (Trautwein et al., 1986), or by stabilizing the open state via the $\alpha$-subunit of the GTP binding protein $\mathrm{G}_{\mathrm{s}}$ (Yatani et al., 1987). L-type channels occur in peripheral and central ncurons, smooth muscle, invertebrate skeletal muscle and heart. Their biological function in vertebrate skeletal muscle has not been established unequivocally, but probably the channel has the same function as in cardiac muscle, i.c. participating in the maintenance of an adequate amount of intracellular $\mathrm{Ca}^{2+}$ for muscle contraction (Ildefonse et al., 1985). However, the channel protein may participate in skcletal muscle excitation contraction-coupling not only as $\mathrm{Ca}^{2+}$ channel but also as a voltage sensor (Berwe et al., 1987; Lamb and Walsh, 1987; Rios and Brum, 1987). L-type $\mathrm{Ca}^{2+}$ channels of different tissues probably are not identical and will be divided up further 
as our knowledge of their clectrophysiological and molccular propertics, their functional significance and their modulation by hormones, ncurotransmitters and drugs expands.

\section{Structural composition of the purified skeletal muscle $\mathrm{Ca}^{2+}$ channel}

Most of the information on the structural composition of the L-type $\mathrm{Ca}^{2+}$ channel originates from studies with rabbit skcletal muscle. SDS-gcl analysis of the purified skeletal CaCB-receptor yiclds several stained bands with apparent molccular weights of $165 \mathrm{kDa}\left(\alpha_{1}\right), 55 \mathrm{kDa}(\beta)$ and $32 \mathrm{kDa}(\gamma)$ in a constant ratio of $1: 1.7: 1.4$ (Sieber et al., 1987). A further protein containing a $130-\left(\alpha_{2}\right)$ and $28-\mathrm{kDa}(\delta)$ disulfide-linked peptide co-purifies in variable amounts with the $\alpha_{1}-, \beta$ - and $\gamma$-subunits of the CaCB-receptor. The $\alpha_{2}$ - and the $\gamma$-peptides are heavily glycosylated, whereas the $\alpha_{1}$ - and $\beta$-subunit contain none or a low amount of carbohydrates (Takahashi el al., 1987). The purified receptor binds all threc major classes of $\mathrm{Ca}^{2+}$ channel blockers (i.e. DHPs, PAAs and BTZs) in a stereospecific manner. The photo-affinity analogues of the 1,4-DHPs and PAAs, azidopine and LU 49888, label only the $165-\mathrm{kDa}\left(\alpha_{1}\right)$ subunit, indicating that this protein carries the drug receptor sites for 1,4-DHPs and PAAs (Galizzi et al., 1986; Sieber el al., 1987; Tanabe et al., 1987; Striessnig et al., 1986, 1987). The constant stoichiometry of the 165-, 55- and 32-kDa proteins suggests that these proteins are constituents of the $\mathrm{Ca}^{2+}$ channel. Further evidence for the existence of a functional complex with this composition comes from studies with antibodics against the $\alpha_{1}$-subunit which precipitate the $\alpha_{1}$-, $\beta$ - and $\gamma$-subunits (Takahashi et al., 1987). Antibodies specific against the $\alpha_{1}$ - or $\beta$-subunits immunoprecipitates the $\alpha_{1}$ - or $\beta$-subunits (Lcung el al., 1988). Furthermore, antibodies specific against the $\alpha_{1}-, \beta$ - and $\gamma$-subunits modulate the $\mathrm{Ca}^{2+}$ current in vivo (Campbell el al., 1988; Morton et al., 1988; Vilven el al., 1988). Attempts to isolate only the $\alpha_{1}$-subunit under non-denaturing conditions have not been successful so far, suggesting that the $\beta$ - and $\gamma$-subunits stabilize the channel in a high-affinity CaCB binding conformation. At present, it is not known whether or not the $130 / 28-\mathrm{kDa}$ protein belongs also to this structure (Leung et al., 1988) or is only a contaminant.

\section{Phosphorylation of the purified CaCB-receptor}

The 165- and 55-kDa subunits of the purified CaCB-receptor are phosphorylated readily by cAMP-dependent protein kinase (Curtis and 
Table 1 Kinase-specific phosphopeptides of the skeletal muscle CaCB-receptor

\begin{tabular}{lll}
\hline & \multicolumn{2}{c}{ Phosphopeptide number } \\
Protein kinase & $165 \mathrm{kDa}$ & $55 \mathrm{kDa}$ \\
\hline & & 7 \\
CAMP-kinase & 1,10 & 1,3 \\
cGMP-kinase & 1,2 & $7 / 8$ \\
Protein kinase C & none & 9,10 \\
Casein kinase II & 7,11 & \\
\hline
\end{tabular}

The purified receptor was phosphorylated by each kinase as described by Jahn et al., (1988). The phosphorylated subunits were separated by SDS-gel electrophoresis. Individual gel pieces containing the phosphorylated $\alpha_{1}$ - or $\beta$-subunit were digested by trypsin over night. The phosphopeptides were then separated by 2-D thin-layer chromatography. The number of the kinase-specific phosphopeptide(s) is shown. Sce also Jahn et al. (1988).

Catterall, 1985; Flockerzi et al., 1986a,b) and other kinases in vitro (Nastainczyk el al., 1987; O'Callahan et al., 1988; Jahn el al., 1988). The $\alpha_{1}$-subunit is a good substrate for cAMP-kinase and cascin kinase II, whereas the $55-\mathrm{kDa}$ subunit is preferentially phosphorylated by protein kinase $\mathrm{C}$ and cGMP-dependent protein kinase. Two-dimensional peptide maps yicld 11 phosphopeptides from the $165-\mathrm{kDa}$ subunit and 11 from the 55-kDa subunit using these kinases (Jahn el al., 1988). With the exception of protein kinase $\mathrm{C}$, each kinase apparently phosphorylates one or two peptides specifically in each subunit (Table 1). Protein kinase C does not phosphorylate specifically a peptide in the $165-\mathrm{kDa}$ peptide, but modifies rapidly peptide $7 / 8$ of the $55-\mathrm{kDa}$ subunit. Neither the $32-\mathrm{kDa}$ nor the $130 / 28-k D a$ peptides are phosphorylated by the above-mentioned kinases. At physiological concentrations cAMP-dependent protein kinase incorporates 1 mole phosphate per mole $165-\mathrm{kDa}$ subunit within $10 \mathrm{~min}$ (Curtis and Cattcrall, 1985; Nastainczyk et al., 1987). This suggests that the phosphorylation of this site may be functionally important. A sccond site is phosphorylated during prolonged incubation. The rapidly phosphorylated peptide was isolated and sequenced. The phosphorylated amino acid was identified as Ser 687 of the deduced amino acid sequence of the $\alpha_{1}$-subunit (Röhrkasten el al., 1988). This scrine is located in the cytoplasmic loop between transmembrane regions II and III (sce Fig. 1). It is possible that in vivo cAMP-dependent phosphorylation of this serine increases the open state probability of the $\mathrm{Ca}^{2+}$ channel. 


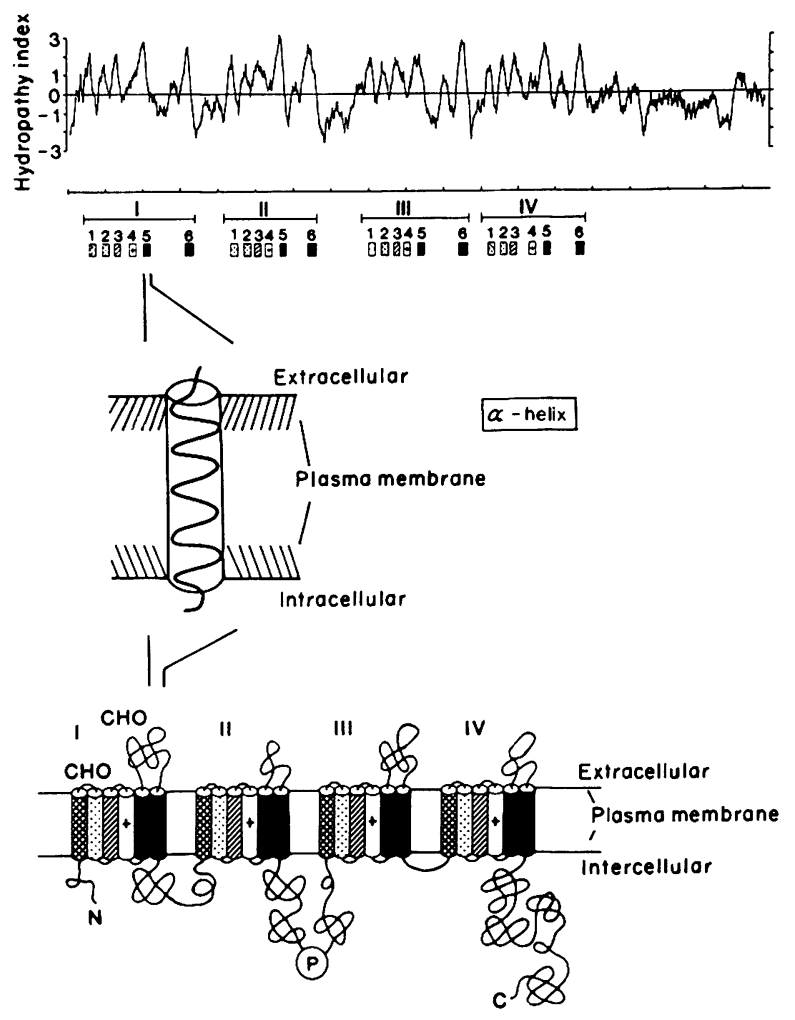

Fig. 1 Hydrophobicity profile and transmembrane topology of the skeletal muscle $\mathrm{Ca}^{2+}$ channel $\alpha_{1}$-subunit. The hydrophobicity profile of the $\alpha_{1}$-subunit according to Tanabe et al. (1987). Positive indices represent hydrophobic amino acid regions. The protein consists of four homologous domains (I, II, III, IV) each composed of six membrane spanning helices $(1,2,3,4,5,6)$. Transmembrane regions are based on their hydropathy value, polarity index and hydrophobic moment analysis according to Chou and Fasman (1978). The homologous regions (I, II, III, IV) each containing six transmembrane spirals are shown linearly. They are supposed to form the ionic pore. The carboxy- and amino-termini are located at the cytoplasmic site of the plasma membrane. The phosphorylation site of cAMP. dependent protein kinase, serine residue 687 , is indicated between domains II and III.

\section{Structure of the $\alpha_{1}$ - and $\beta$-subunits of the skeletal muscle $\mathrm{Ca}^{2+}$ channel}

Identification and cloning of the $\alpha_{1}$ - subunit of the $\mathrm{Ca}^{2+}$ channel from skcletal muscle was a major step in $\mathrm{Ca}^{2}{ }^{+}$channol rescarch (Tanabe el al., 
1987). The cloned rabbit skcletal muscle $\alpha_{1}$-subunit has $29 \%$ homology with the voltage-dependent $\mathrm{Na}^{+}$channel. It is assumed that four homologous regions, each consisting of five hydrophobic $\alpha$-helices (S1, S2, S3, Sj and S6) and onc hydrophilic $\alpha$-helix (S4), span the membrane and form the $\mathrm{Ca}^{2+}$ channel pore (Fig. 1). S4, which is present in each transmembrane region, is a positively charged helix that could act as a voltage sensor. A homologous helix is found in other voltage-activated ion channcls, i.e the $\mathrm{Na}^{+}$channel of ecl, fly and rat and the $\mathrm{K}^{+}$channel of various tissues. The positive charges of the $\mathrm{S} 4$ segment could respond to a change in the membrane potential by a transmembrane shift of its positive charges, and thereby affect the open/closed state of the channel.

The primary structure of the rabbit skeletal muscle $\beta$-subunit has been deduced from the cloned cDNA. The cDNA has a length of 1.85 kilobase. The deduced peptide consists of 524 amino acids with a $M_{r}$ of $58 \mathrm{kDa}$. The primary structure of the $\beta$-subunit agrees with that of a peripheral membranc protein. It contains four homologous $\alpha$-helices (Fig. 2). Analysis of the primary structure reveals two further apparently specific protein kinase $\mathrm{C}$ phosphorylation sites. This is interesting since the $\beta$-subunit is preferentially phosphorylated by protein kinase $C$ in iilro. Furthermore,

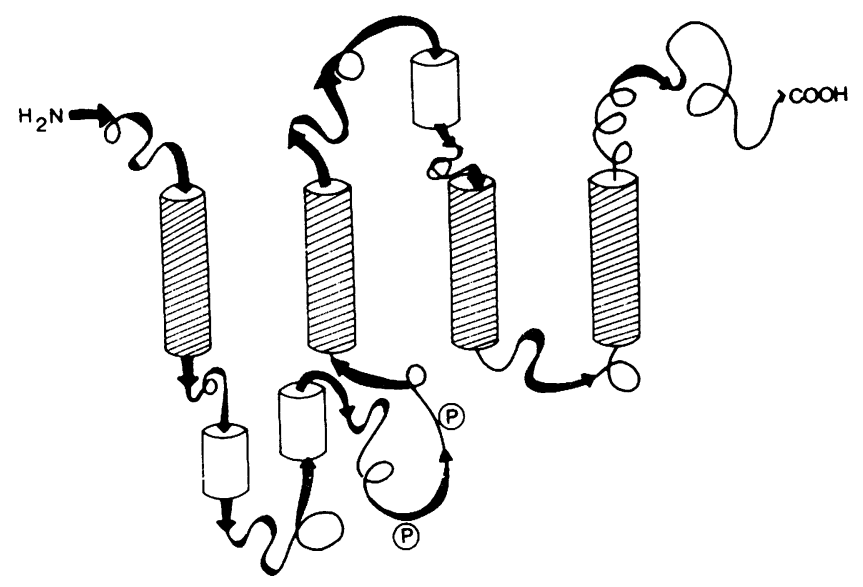

Fig. 2 Predicted secondary structure of the $\beta$-subunit of the skeletal muscle $\mathrm{Ca}^{2+}$ channel. The secondary structure of the deduced amino acid sequence was predicted by the method of Garnier et al. (1978). The $\beta$-subunit contains four hydrophilic helical regions (shaded rods), each composed of 26-33 amino acids. The helices are joined by $\beta$-sheets (arrows) and coils. These secondary structures are interrupted at three positions by helical structures with a length of 10-15 amino acids (open rods). The in vitro phosphorylation sites are indicated by $P$. The site closer to the amino terminus is the major in vitro phosphorylation site of $\mathrm{CAMP}$-dependent protein kinase. 
there is ample evidence that protcin kinase $\mathrm{C}$ alters L-type channel function in vivo (Kaczmarek, 1987). In addition, the primary sequence contains a site specific for cGMP-dependent protein kinase. This was expected from the in vilro phosphorylation experiments (sce Table 1).

The biological significance of these primary structures remains to be clucidated. Antibodics against the $\beta$-subunit enhance $\mathrm{Ca}^{2+}$ currents through L-type channels and prevent the blocking action of nitrendipine (Vilven $e$ l al., 1988), whereas antibodics against the $\gamma$-subunit inhibit $\mathrm{Ca}^{2+}$ current (Campbell el al., 1988). This suggests that the two smaller subunits of the skeletal muscle $\mathrm{Ca}^{2+}$ channel are necessary for proper channel function.

The primary structure of the $\gamma$-subunit is not known. However, the primary structure of the $130-\mathrm{kDa}\left(\alpha_{2}\right)$ protein has been deduced from cloned rabbit skeletal muscle cDNA (Ellis et al., 1988). The $\alpha_{2}$ protein has the sequence of a hydrophilic protein and may contain up to threc transmembrane helices and eight extracellular $\mathrm{N}$-glycosylation sitcs. This predicted topography is in accordance with the finding that the purified protein is heavily glycosylated. Hybridization studies show that the mRNA for the $\alpha_{2}$ protein is expressed in many tissues, whereas the cDNA for the skeletal muscle $\alpha_{1}$-subunit hybridizes only weakly or not at all to the messenger RNA from other tissues (Ellis el al., 1988). Although these data are not conclusive, they support the notion that the $130 / 28-\mathrm{kDa}\left(\alpha_{2} / \delta\right)$ protein may not be an essential part of the calcium channcl.

\section{Identification of L-type $\mathrm{Ca}^{2+}$ channel proteins in other tissues}

A $\mathrm{Ca}^{2+}$ channel $\alpha_{1}$-subunit of a slightly larger size than that of rabbit skeletal muscle has been identificd in brain, smooth muscle and heart by northern blot analysis of the respective mRNA (Table 2). This difference in size is supported by photo-affinity labelling of the high-affinity receptor for CaCBs. Azidopine and LU 49888 identify a $195-\mathrm{kDa}$ protein in a partially purified preparation of the bovine cardiac muscle CaCB-receptor (Schncider and Hofmann, 1988). An identically sized $\alpha$-subunit is labelled in hippocampus (Striessnig el al., 1988). These differences are not caused by species differences, since a monoclonal antibody to the $\alpha_{1}$-subunit of rabbit skeletal muscle recognizes the same subunit in the skelctal muscle of guinea pig, hamster, rat, cow and pig, but docs not bind to the bovine heart subunit. This suggests that the differences are real and reside in the primary sequence of the $\alpha$-subunits from different tissues. 
Table 2 Size of the putative $\alpha$-subunit of the $\mathrm{Ca}^{2+}$ channel in other tissues

\begin{tabular}{llcc}
\hline & & \multicolumn{2}{c}{ Size of putative $\alpha_{1}$-subunit } \\
\cline { 3 - 4 } Tissue & Species & Protein $(\mathrm{kDa})$ & mRNA $(\mathrm{kB})$ \\
\hline Skeletal muscle & rabbit & 165 & 6.2 \\
Heart & cow & 195 & 8.3 \\
Lung & cow & - & 8.2 \\
Brain & guinea pig & 195 & 8.1 \\
\hline
\end{tabular}

Membranes or a partially purified preparation of the CaCB-receptor were affinity-labelled with azidopine or LU 49888. The molecular weight was determined by SDS-gel electrophoresis. The size of the mRNA was determined by hybridization with a probe derived from the cloned $\alpha_{1}$-subunit of the rabbit skeletal CaCB-receptor. For further detail see Sicber et al. (1987), Schneider and Hofmann (1988) and Striessnig et al. (1988).

\section{Reconstitution of an L-type $\mathrm{Ca}^{2+}$ channel from the skeletal muscle CaCB-receptor}

The purified dihydropyridine receptor from skeletal muscle has been reconstituted into phospholipid vesicles which were fused with a phospholipid bilayer (Flockerzi el al., 1986a; Hymel el al., 1988; Ma and Coronado, 1988; Pelzer el al., 1988; Talvenhcimo el al., 1987). In agreement with whole-cell recording data, the reconstituted protein channel has a singlcchannel conductance of about 20 pS (Flockerzi el al., 1986a; Pelzer el al., 1988; Talvenheimo el al., 1987). Its open state probability $\left(p_{0}\right)$ is reduced by the $\mathrm{Ca}^{2+}$ channel blockers gallopamil and PN 200-110, and increases in the presence of the $\mathrm{Ca}^{2+}$ channel agonist Bay $\mathrm{K} 8644$. The $p_{0}$ is also increased several fold by the addition of ATP. $\mathrm{Mg}$ and the catalytic subunit of cAMP-dependent protein kinase (Flockerzi et al., 1986a; Hymel el al., 1988; Pelzer el al., 1988). These results suggest that the reconstituted channel has some propertics of the cardiac L-type $\mathrm{Ca}^{2+}$ channel. Further analysis of the single-channel kinetics showed that open and closed times of the reconstituted channel are about 10 times longer than that of an in vivo cardiac muscle L-type channel (Pelzer el al., 1988), indicating that the reconstituted channcl has properties which differ from that of the cardiac muscle channcl. The slower channel kinctics of the purified receptor are not caused by protcolysis of the receptor during purification. The same kinetics were obtained when solubilized microsomal membranes were reconstituted. 
Both preparations, the solubilized membrancs and the purificd receptor, contain a sccond channcl with a conductance around $10 \mathrm{pS}$ ( $\mathrm{Ma}$ and Coronado, 1988; Pelzer el al., 1988; Talvenheimo el al., 1987). The $p_{()}$of the channel showing the smaller conductance was not affected by phosphorylation, $\mathrm{Ca}^{2+}$ channcl blockers or agonists (Pclzcr el al., 1988). So far, an interconversion of a small non-rcgulated into a large regulated conductance has not becn obscrved (Pclzer el al., 1988). The two conductances could be distinguished further by the voltage-dependence of $p_{\text {o) }}$. The small conductance showed a regular voltage dependence of its open state probability, whereas the large conductance yiclded a bell-shaped dependency. $p_{\mathrm{O}}$, was greatest at a membrane potential around $0 \mathrm{mV}$ (Pelzer el al., 1988). These differences in electrophysiological parameters clearly distinguish the two conductances.

\section{Conclusions}

The biochemical identity of these conductances is not clear at present. Recent reconstitution experiments of the isolated $\alpha_{1}$-subunit suggest that the 165-kDa subunit is the $\mathrm{Ca}^{2+}$-conducting unit (Pclzcr et al., 1988). This conclusion is supported by experiments in which the cloned cDNA of the $\alpha_{1}$-subunit was expressed in embryonic muscle cells from dysgenic micc (Tanabe et al., 1988). The dysgenic myotubes do not express the $6.5-\mathrm{kB}$ mRNA of the $\alpha_{1}$-subunit and are defective in EC-coupling. The intranuclear injection and the expression of the cloned $\alpha_{1}$-subunit mRNA in myotubes of dysgenic mice restores EC-coupling and a slow L-typc $\mathrm{Ca}^{2+}$ channcl in these cells. Interestingly, the T-tubular voltage sensor and the $\mathrm{Ca}^{2+}$ channel is regaincd together with the expression of the $\alpha_{1}$-subunit, suggesting that both functions require the $\alpha_{1}$-subunit. These two functions may not depend alone on the presence of the $165-\mathrm{kDa}\left(\alpha_{1}\right)$-subunit, but correct functioning may require the presence of the other subunits. This conclusion is supported also by the modulatory effect of $\beta$ - (Vilven el al., 1988) and $\gamma$-(Campbell el al., 1988) subunit-specific antibodics on $\mathrm{Ca}^{2+}$ current (sec above). Furthermore, the survival of a $\mathrm{Ca}^{2+}$ channel reconstituted from $\mathrm{T}$-tubular membranes increases dramatically in the presence of activated $\mathrm{G}_{\mathrm{s}}$ (Yatani el al., 1988). It is likely, therefore, that the $165-\mathrm{kDa}$ subunit contains the $\mathrm{Ca}^{2+}$-conducting part of a L-type $\mathrm{Ca}^{2+}$ channcl, which requires in vivo the presence of other smaller subunits and $\mathrm{G}$ proteins for proper function.

\section{Acknowledgements}

We thank Mrs Siepmann for her work on the figures. This work was supported by Fonds der Chemischen Industric and Deutsche Forschungsgemcinschaft. 


\section{References}

Berwe, D., Gottschalk, G. and Lüttgau, C. H. (1987). Effects of the calcium antagonist gallopamil (D600) upon excitation-contraction coupling in toe muscle fibres of the frog. J. Physiol. 385, 693-707.

Campbell, K. P., Leung, $\Lambda$. T., Sharp, A. H., Imagawa, T. and Kahl, S. D. (1988). $\mathrm{Ca}^{2+}$ channel antibodies: Subunit-specific antibodies as probes for structure and function. In The Calcium Channel: Structure, Function and Implication (eds M. Morad, W. G. Nayler, S. Kazda and M. Schramm), pp. 586-600. Springer Verlag, Berlin.

Chou, P. Y. and Fasman, G. D. (1978). Prediction of the secondary structure of proteins from their amino acid sequence. Adv. Enzymol. 47, 45-148.

Curtis, B. M. and Catterall, W. A. (1985). Phosphorylation of the calcium antagonist receptor of the voltage-sensitive calcium channel by $\mathrm{cAMP}$-dependent protein kinase. Proc. Natl Acad. Sci. USA 82, 2528-2532.

Ellis, S. B., Williams, M. E., Ways, N. R., Brenner, R., Sharp, A. H., Leung, A. T., Campbell, K. P., McKenna E., Koch, W. J., Hui, A., Schwartz, A. and Harpold, M. M. (1988). Sequence and expression of mRNAs encoding the $\alpha_{1}$ and $\alpha_{2}$ subunits of a DHP-sensitive calcium channel. Science, 241, 1661-1664.

Flockerzi, V., Oeken, H.-J. and Hofmann, F. (1986a). Purification of a functional receptor for calcium channel blockers from rabbit skeletal muscle microsomes. Eur. J. Biochem. 161, 217-224.

Flockerzi, V., Oeken, H.-J., Hofmann, F., Pelzer, D., Cavaliè, A. and Trautwein, W. (1986b). The purified dihydropyridine binding site from skeletal muscle Ttubules is a functional calcium channel. Nature 323, 66-68.

Galizzi, D.-P., Borsotto, M., Barhanin, J., Fosset, M. and Lazdunski, M. (1986). Characterization and photoaffinity labeling of receptor sites for the $\mathrm{Ca}^{2+}$ channel inhibitors d-cis-diltiazem, ( \pm )-bepridil, desmethoxyverapamil, and (+)-PN 200110 in skeletal muscle transverse tubule membranes. J. Biol. Chem. 261, 1393-1397.

Garnier, J., Osguthorpe,, D. J. and Robson, B. (1978). Analysis of the accuracy and implications of simple methods for predicting the secondary structure of globular proteins. J. Mol. Biol. 120, 97-120.

Hofmann, F., Nastainczyk, W., Röhrkasten, A., Schneider, T. and Sieber, M. (1987). Regulation of the L-type calcium channel. TIPS 8, 393-398.

Hymel, L., Striessnig, J., Glossmann, H. and Schindler, H. (1988). Purified skeletal muscle 1,4-dihydropyridine receptor forms phosphorylation-dependent oligomeric calcium channels in planar bilayers Proc. Natl Acad Sci. USA 85, 4290-4294.

Ildefonse, M., Jacquemond, V., Rougier, O., Renaud, J. F., Fosset, M. and Lazdunski, M. (1985). Excitation contraction coupling in skeletal muscle: Evidence for a role of slow $\mathrm{Ca}^{2+}$ channels using $\mathrm{Ca}^{2+}$ channel activators and inhibitors in the dihydropyridine series. Biochem. Biophys. Res. Commun. 129, 904-909.

Jahn, H., Nastainczyk, W., Röhrkasten, A., Schneider, T. and Hofmann, F. (1988). Site specific phosphorylation of the purified receptor for calcium channel blockers by $\mathrm{C} \Lambda \mathrm{MP}$-, cGMP-dependent protein kinase, protein kinase $\mathrm{C}$, calmodulindependent protein kinase II, and casein kinase II. Eur J. Biochem. 178, 535-542.

Kaczmarek, L. K. (1987). The role of protein kinase C in the regulation of ion channels and neurotransmitter release. TINS 10, 30-34.

Lamb, G. D. and Walsh, T. (1987). Calcium currents, charge movement and dihydropyridine binding in fast- and slow-twitch muscle of rat and rabbit. $J$. Physiol. 393, 595-617. 
Leung, A. T., Imagawa, T., Block, B., Franzini-Armstrong, C. and Campbell, K.P. (1988). Biochemical and ultrastructural characterization of the 1,4dihydropyridine receptor from rabbit skeletal muscle. J. Biol. Chem. 263, 994-1001.

Ma, J. and Coronado, R. (1988). Heterogeneity of conductance states in calcium channels of skeletal muscle. Biophys. J. 53, 387-395.

Morton, M. E., Caffrey, J. M., Brown, A. M. and Froehner, S. C. (1988). Monoclonal antibody to the $\alpha_{1}$ subunit of the dihydropyridine-binding complex inhibits calcium currents in BC3H1 myocytes. J. Biol. Chem. 263, 613-616.

Nastainczyk, W., Röhrkasten, A., Sieber, M., Rudolph, C., Schächtele, C., Marme, D. and Hofmann, F. (1987). Phosphorylation of the purified receptor for calcium channel blockers by cAMP kinase and protein kinase C. Eur. J. Biochem. 169, 137-142.

Nowycky, M. C., Fox, A. P. and Tsien, R W. (1985). Three types of neuronal calcium channel with different calcium agonist sensitivity. Nature 316, 440-443.

O'Callahan, C. M., Ptasienski, J. and Hosey, M. M. (1988). Phosphorylation of the $165-\mathrm{kDa}$ dihydropyridine/phenylalkylamine receptor from skeletal muscle by protein kinase C. J. Biol. Chem 263, 17,342-17,349.

Pelzer, D., Cavalié, A., Flockerzi, V., Hofmann, F. and Trautwein, W. (1988). Reconstitution of solubilized and purified dihydropyridine receptor from skeletal muscle microsomes as two single calcium channel conductances with different functional properties. In The Calcium Channel: Stucture, Function and Implication (eds M. Morad, W. G. Nayler, S. Kazda and M. Schramm), pp. 217-230. SpringerVerlag, Berlin.

Rios, E. and Brum, G. (1987). Involvement of dihydropyridine receptors in excitation-contraction coupling in skeletal muscle Nature 235, 717-720.

Röhrkasten, A., Meyer, H., Nastainczyk, W., Sieber, M. and Hofmann, F. (1988). CAMP-dependent protein kinase rapidly phosphorylates Ser 687 of the rabbit skeletal muscle receptor for calcium channel blockers. J. Biol Chem. 263, $15,325-15,329$.

Schneider, T. and Hofmann, F. (1988). The bovine cardiac receptor for calcium channel blockers is a $195 \mathrm{kDa}$ protein. Eur. J. Biochem. 174, 127-135.

Sieber, M., Nastainczyk, W., Zubor, V., Wernet, W. and Hofmann, F. (1987). The 165-kDa peptide of the purified skeletal muscle dihydropyridine receptor contains the known regulatory sites of the calcium channel. Eur.J. Biochem. 167, 117-122.

Striessnig, J., Moosburger, K., Goll, D., Ferry, D. R. and Glossmann, H. (1986). Stereoselective photoaffinity labelling of the purified 1,4-dihydropyridine receptor of the voltage-dependent calcium channel. Eur. J. Biochem. 161, 603-609.

Striessnig, J., Knaus, H.-G., Grabner, M., Moosburger, K., Seitz, W., Lietz, H. and Glossmann, H. (1987). Photoaffinity labelling of the phenylalkylamine receptor of the skeletal muscle transverse-tubule calcium channel. FEBS Lett. 212, 247-253.

Striessnig, J., Knaus, H.-G. and Glossmann, H. (1988). Photoaffinity-labelling of the calcium-channel-associated 1,4-dihydropyridine and phenylalkylamine receptor in guinea-pig hippocampus. Biochem. J. 253, 39-47.

Takahashi, M., Seagar, M. J., Jones, J. F., Reber, B. F. X. and Catterall, W. A. (1987). Subunit structure of dihydropyridine-sensitive calcium channel from skeletal muscle. Proc. Natl Acad. Sci. USA 84, 5478-5482.

Talvenheimo, J. A., Worley, III J. F. and Nelson M. T. (1987). Heterogeneity of calcium channels from a purified dihydropyridine receptor preparation. Biophys. J. 52, 891-899. 
Tanabe, T., Takeshima, H., Mikami, A., Flockerzi, V., Takahashi, H., Kangawa, K., Kojima, M., Matsuo, H., Hirose, T. and Numa, S. (1987). Primary structure of the receptor for calcium channel blockers from skeletal muscle. Nature (Lond.) 328, 313-318.

Tanabe, T., Beam, K. G., Powell, J. A. and Numa, S. (1988). Restoration of excitation-contraction coupling and slow calcium current in dysgenic muscle by dihydropyridine receptor complementary DNA. Nalure, 366, 131-139.

Trautwein, W., Kameyama, M., Hescheler, J. and Hofmann, F. (1986). Cardiac calcium channels and their transmitter modulation. Progress in Zoology 33, 163-182.

Vilven, J. Lcung, A. T., Imagawa, T., Sharp, A. H., Campbell, K. P. and Coronado, R. (1988). Interaction of calcium channels of skeletal muscle with monoclonal antibodies specific for its dihydropyridine receptor. Biophys. J. 53, $556 \mathrm{a}$

Yatani, A., Codina, J., Imoto, Y., Reeves, J. P., Birnbaumer, L. and Brown, A. M. (1987). A G protein directly regulates mammalian cardiac calcium channels. Science 238, 1288-1292.

Yatani, A., Imoto, Y., Codina, J., Hamilton, S. L., Brown, A. M. and Birnbaumer, L. (1988). The stimulatory $G$ protein of adenyly] cyclase, Gs, also stimulates dihydropyridine-sensitive $\mathrm{Ca}^{2+}$ channels. J. Biol. Chem. 263, 9887-9895. 